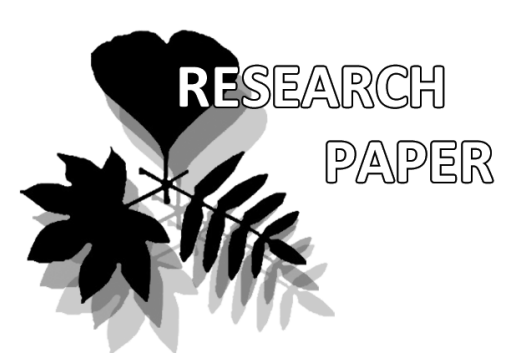

Ludmila V. Gagarina ${ }^{1 *}$

e-mail: gagarinalv@binran.ru

Lena N. Poryadina ${ }^{2}$

e-mail: poryadina-lena@rambler.ru

Sergey V. Chesnokov ${ }^{1}$

e-mail: lukinbrat@mail.ru

Liudmila A. Konoreva ${ }^{1,3}$

e-mail: ajdarzapov@yandex.ru

${ }^{1}$ Komarov Botanical Institute RAS, St. Petersburg, Russia

${ }^{2}$ Institute for Biological Problems of Cryolithozone SB RAS, Yakutsk, Russia

${ }^{3}$ The Polar-Alpine Botanical Garden and Institute, Kola Science Centre RAS, Apatity, Russia

* corresponding author

\section{The lichen genus Usnea Dill. ex Adans. in the Sakha Republic (Yakutia)}

\author{
Ludmila V. Gagarina ${ }^{1 *}$, Lena N. Poryadina ${ }^{2}$, Sergey V. Chesnokov ${ }^{1}$ \\ \& Liudmila A. Konoreva ${ }^{1,3}$
}

Published online: 31.07.2017

\begin{abstract}
A B S T R A C T
The occurrence of lichens belonging to the genus Usnea was studied in Yakutia. Eight species have been revealed: U. barbata (L.) F.H. Wigg., U. cavernosa Tuck., U. dasypoga (Ach.) Nyl., U. glabrescens (Nyl. ex Vain.) Vain., U. birta (L.) W.H. Wigg., U. lapponica Vain., U. longissima Ach. and U. subfloridana Stirt. Distribution maps, an identification key and notes with diagnostic features and distribution data for each species are provided.

K e y w o r d s : lichens, Usnea, identification key, Yakutia

\section{P E 3 Ю M E}

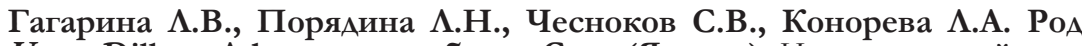
Usnea Dill. ex Adans. в республике Саха (Якутия). Изучены мишайники из рода Usnea в Якутии. Выявлено восемь видов: U. barbata (L.) F.H. Wigg., U. cavernosa Tuck., U. dasypoga (Ach.) Nyl., U. glabrescens (Nyl. ex Vain.) Vain., U. hirta (L.) W.H. Wigg., U. lapponica Vain., U. longissima Ach., и U. subfloridana Stirt. Приведены карты распространения видов. Составлен кАюч Аля опреАеления видов и даны краткие видовые особенности.
\end{abstract}

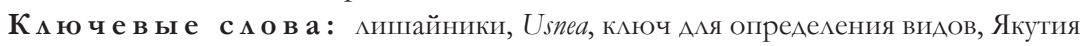

Lichenological investigations have been carried out in the Sakha Republic (Yakutia) for more than 100 years. At present, 813 species are known (Andreev 2004, Poryadina 2005, Zhurbenko et al. 2005, Søchting \& Figueras 2007 , Vershinina et al. 2012, 2015, Zhurbenko \& Vershinina 2014, Ahti et al. 2015, Chesnokov et al. 2015, 2016, Konoreva et al. 2016). Further studies, however, are revealing additional species for Yakutia as well as new localities, indicating knowledge is far from complete.

The genus Usnea (Parmeliaceae, Ascomycota) consists of more than 300 widely distributed species. 40 species are known from Russia. The genus Usnea includes fruticose lichens with a central axis consisting of a cartilaginous strand of longitudinal hyphae. Thallus attached by a holdfast. Branches cylindrical, fusiform, tapering or irregular, with or without papillae, fibrils, soralia, and pseudocyphellae. Cortex composed of radially or irregularly oriented hyphae. Medulla lax, dense or compact, sometimes pink-pigmented. Ascomata zeorine apothecia, rare in most species. Photobiont trebouxioid. Cortex contains usnic acid. Medulla contains diverse secondary metabolites (Halonen et al. 1998, Articus 2004, Randlane et al. 2009, Clerc 2011).

\section{MATERIAL AND METHODS}

Lichens in the herbarium of the Institute for Biological Problems of Cryolithozone of the Siberian Branch of
RAS were revised in 2016. Materials collected by S.V. Chesnokov and L.A. Konoreva from expeditions in Aldan and Neryungri Regions were also studied. Lichen identification was carried out by L.V. Gagarina. M.P. Zhurbenko identified lichenicolous fungi growing on Usnea thalli.

Morphology and anatomy were studied using a light microscope and a dissecting microscope. HPTLC was performed according to standard procedures (Culberson \& Ammann 1979, Kranner et al. 2002), using solvent system $\mathrm{A}$ and $\mathrm{B}$.

Samples from these expeditions were deposited in the herbaria of the Komarov Botanical Institute (LE) and the Institute for Biological Problems of Cryolithozone Siberian Branch of RAS (SASY).

\section{RES U LT S}

In total, 8 species belonging to the genus Usnea are here accepted as occurring in Yakutia: U. barbata (L.) F.H. Wigg., U. cavernosa Tuck., U. dasypoga (Ach.) Nyl., U. glabrescens (Nyl. ex Vain.) Vain., U. birta (L.) W.H. Wigg., U. lapponica Vain., U. longissima Ach. and U. subfloridana Stirt. According to the literature, an additional species, U. articulata (L.) Hoffm., was reported from Central Yakutsk floristic region. However, $U$. articulata is not accepted here in the list of species, because all specimens were previously misidentified (Poryadina 2005, Vershinina et al. 2012, 2015). The distributional 
ranges of $U$. hirta and U. longissima have decreased in Yakutia. At the same time, U. cavernosa, U. glabrescens and U. subfloridana have expanded in range in this region.

Distribution maps, an identification key and notes with principal diagnostic features and distribution data for each species are provided.

\section{Key to Usnea in the Sakha Republic (Yakutia)}

1. Main branches decorticate, the majority of branches distinct, with numerous perpendicular fibrils; thallus very long, up to several meters U. longissima

1. Main branches persistently corticate, branches usually divided and always persistently corticated; thallus shorter (never longer than $60 \mathrm{~cm}$ )

2. Thallus pendent 3

2. Thallus shrubby to subpendent 7

3. Older parts forming sausage-like segments

[U. articulata]

3. Older parts not forming sausage-like segments 4

4. Papillae, isidia and soralia absent ........................................ 5

4. Papillae, isidia and soralia present .

5. Branches conspicuously foveolate and ridged; fibrils absent to scarce

U. cavernosa

5. Branches slightly or distinctly foveolate and ridged; fibrils scarce to numerous

U. barbata

6. Thallus not divided into regular segments by annual cracks; soralia often bearing isidia .

U. dasypoga

6. Thallus divided into irregular segments by annular cracks; isidia few or absent ....

U. barbata

7. With papillae 8

7. Without papillae; isidia numerous U. birta

8. Soralia bearing isidia U. subfloridana

8. Soralia not bearing isidia ... 9

9. Thallus mainly anisotomic-dichotomous; soralia expanded and irregular or bracelet-like

U. lapponica

9. Thallus mainly isotomic-dichotomous; soralia punctiform

U. glabrescens

\section{Species characteristics and specimens examined}

\section{Usnea barbata (L.) F.H. Wigg.}

The species is very polymorphic. Characterised by having a pendent thallus, divided into irregular segments by annular cracks. Branches uneven in thickness. Base blackened, fibrils few to numerous, isidia few or absent. The main diagnostic features are its thin cortex, the strongly irregular branches and inflated segments.

Two chemotypes have been recorded: (1) medulla with salazinic acid, cortex with usnic acid; (2) medulla with salazinic, barbatic/diffractaic acid, cortex with usnic acid.

The species occurs in Lensk Region according to herbarium collections and own materials, and is also reported from Olekminsk Region (Vershinina et al. 2015) (Fig. 1A).

Specimens examined: LENSK REGION, $17 \mathrm{~km} \mathrm{E}$ from village Vitim, wood sorrel spruce forest, branches of Picea sp., 05.07.1989, leg. Isaev A.P. (SASY, Us 8); bor- der with Irkutsk Region, right bank of the river Vitim $\left(59^{\circ} 27^{\prime} 12^{\prime \prime} \mathrm{N}, 112^{\circ} 55^{\prime} 58^{\prime \prime} \mathrm{E}\right), 4 \mathrm{~km}$ downstream from the river Talaya $\left(59^{\circ} 08^{\prime} 18^{\prime \prime} \mathrm{N}, 112^{\circ} 40^{\prime} 52^{\prime \prime} \mathrm{E}\right)$, mixed forest, on the branches of Picea sp., 12.06.2004, leg. Poryadina L. N. (SASY, Us 27).

\section{Usnea cavernosa Tuck.}

The species is characterised by having a pendulous thallus, with parallel branches. Branches foveolate and ridged. Base pale, fibrils absent to scarce, papillae absent, soralia and isidia absent. The main diagnostic feature is the foveolate and ridged branches.

One chemotype has been recorded: medulla with salazinic acid, cortex with usnic acid.

The species is widespread in Yakutia (Fig. 1B).

Specimens examined: ALDAN REGION, right bank of the river Aldan $\left(58^{\circ} 49^{\prime} 521^{\prime \prime} \mathrm{N}, 127^{\circ} 42^{\prime} 4566^{\prime \prime E}\right.$, sprucelarch forest, on the branches of Picea sp., 21.07.2015, leg. Poryadina L.N. (SASY, Us 87); left bank of the river Aldan, firth of the river Unil'ya, $78 \mathrm{~km}$ upper village Ugino $\left(58^{\circ} 45^{\prime} 36^{\prime \prime} \mathrm{N}, 128^{\circ} 02^{\prime} 24^{\prime \prime} \mathrm{E}\right)$, spruce-pine forest, 24.06.1980, leg. Zaharova V.I. (SASY, Us 74); rock on the left bank of the river Aldan, near firth of the river Timpton $\left(58^{\circ} 44^{\prime} 11^{\prime \prime} \mathrm{N}\right.$, $\left.127^{\circ} 10^{\prime} 31^{\prime \prime E}\right), 15.07 .2015$, leg. Konoreva L.A. (LE); near village Zarechnyi $\left(58^{\circ} 46^{\prime} 34.4^{\prime \prime} \mathrm{N}, 126^{\circ} 25^{\prime} 45.3^{\prime \prime} \mathrm{E}\right)$, fir forest, Picea sp., 12.07.2015, leg. Poryadina L.N. (SASY, Us 85). ZHIGANSK REGION, right bank of the river Lena, water gap of the river Uchuge (left influx of the river Nimingde) $\left(67^{\circ} 14^{\prime} 18.8^{\prime \prime} \mathrm{N}, 124^{\circ} 16^{\prime} 1.7^{\prime \prime} \mathrm{E}\right)$, pyroloideae fir forest with wild rose, 20.07.1958, leg. Dobretsova L.A. (SASY). KOBYAISK REGION, near river Undyulyung, near orifice river Byrand'ya $\left(66^{\circ} 13^{\prime} 49^{\prime \prime} \mathrm{N}, 126^{\circ} 58^{\prime} 36^{\prime \prime} \mathrm{E}\right)$, fir forest, on the branches and bark of Picea sp., 12.07.1990, leg. Fes'ko N.N. (SASY, Us 61); left bank of the river Lyunkyubei $\left(64^{\circ} 9^{\prime} 37^{\prime \prime} \mathrm{N}, 126^{\circ} 58^{\prime} 59^{\prime \prime} \mathrm{E}\right)$, fir forest, on the branches of Picea sp., 08.07.2002, leg. Poryadina L.N. (SASY, Us 58); firth of the river Sagandzhi $\left(65^{\circ} 27^{\prime} 9^{\prime \prime} \mathrm{N}, 126^{\circ} 58^{\prime} 41^{\prime \prime E}\right)$, sprucelarch forest, on the branches of Picea sp., 25.05.1985, leg. Volotovskii K.A. (SASY, Us 12); SW branches of the Verchoyansk Range, valley of the river Yus-Yuryah (64 $\left.52^{\prime}\right)^{\prime \prime} \mathrm{N}$, 1260'36"E), Picea sp., 17.06.1953, leg. Gryaznuhin A.N. (SASY, Us 91). LENSK REGION, right bank of the river Peledui, near island Noochoko-aryyta, $5 \mathrm{~km}$ below village In'yaly $\left(59^{\circ} 30^{\prime} 35^{\prime \prime} \mathrm{N}, 111^{\circ} 17^{\prime} 35^{\prime \prime} \mathrm{E}\right)$, spruce-larch forest, on the branches of Larix sp., 18.08.1953, leg. Kuvaev V.B. (SASY, Us 93); island in firth of river Nyuya $\left(60^{\circ} 32^{\prime} 35^{\prime \prime} \mathrm{N}\right.$, $116^{\circ} 18^{\prime} 38^{\prime \prime E}$ ), old Picea sp., leg. Shcheludyakova V.A. (SASY, Us 94); left bank of the river Lena, Talakanskoe oil and gas field, the top of the hill $\left(59^{\circ} 30^{\prime} 15.1^{\prime \prime} \mathrm{N}, 110^{\circ} 38^{\prime} 58.4^{\prime \prime} \mathrm{E}\right)$, spruce-larch forest, on the branches of Larix sp., leg. Poryadina L.N. (SASY, Us 13); border with Irkutsk Region, right bank of the river Vitim, $4 \mathrm{~km}$ downstream from the river Talaya (59 $\left.08^{\prime} 18^{\prime \prime} \mathrm{N}, 112^{\circ} 40^{\prime} 52^{\prime \prime} \mathrm{E}\right)$, mixed forest, deadwood, on the branches of Picea sp., 12.06.2004, leg. Poryadina L.N. (SASY, Us 26, Us 57, Us 62). NERYUNGRI REGION, 100 $\mathrm{m}$ to $\mathrm{W}$ from highway A-360, between rivers Manahta-1 and Manahta-2 (56 $\left.20^{\prime} 15.4^{\prime \prime} \mathrm{N}, 124^{\circ} 45^{\prime} 51.7^{\prime \prime} \mathrm{E}\right)$, bald mountain with Pinus pumila and Duschekia sp., on the branches of Picea sp., alt. 877 m, leg. Konoreva L.A., Chesnokov S.V. (LE). 

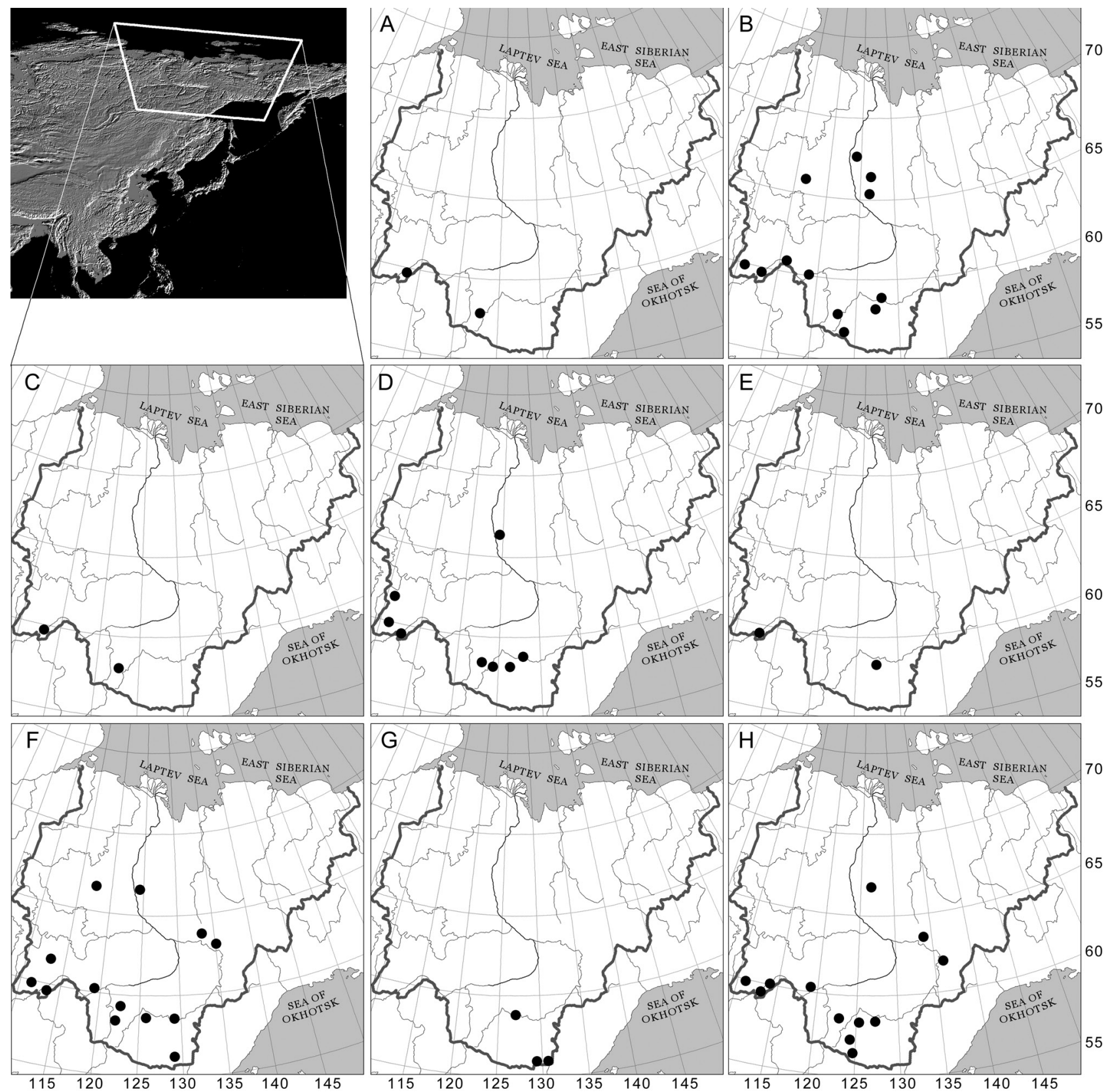

Figure 1 Distribution of Usnea spp. (dots) in Sakha-Yakutia (outlined with solid gray line): A - U. barbata (L.) F.H. Wigg., B - U. cavernosa Tuck., C - U. dasypoga (Ach.) Nyl., D - U. glabrescens (Nyl. ex Vain.) Vain., E - U. birta (L.) W.H. Wigg., F - U. lapponica Vain., G U. longissima Ach., $\mathrm{H}-$ U. subfloridana Stirt. See text for details.

OLENEK REGION, left bank of the river Tyung (below orifice Sr. Salakuta) (66 $\left.35^{\prime} 3^{\prime \prime} \mathrm{N}, 115^{\circ} 50^{\prime} 28^{\prime \prime} \mathrm{E}\right)$, spruce-larch forest, 17.07.1957, leg. Dobretsova L.A. (SASY, Us 92). OLEKMINSK REGION, right bank of the river Biryuk $\left(60^{\circ} 22^{\prime} 12^{\prime \prime} \mathrm{N}, 119^{\circ} 29^{\prime} 25^{\prime \prime} \mathrm{E}\right)$, fir forest, on the branches of Picea sp., 16.07.2008, leg. Poryadina L.N. (SASY, Us 60).

\section{Usnea dasypoga (Ach.) Nyl.}

The species is very polymorphic. Thallus pendulous, base blackened, fibrils and isidia conspicuous and numerous, papillae sparse to abundant, soralia punctiform, often bearing isidia. The main diagnostic features are its pendulous thallus, slightly or distinctly inflated segments.

A single chemotype has been recorded: medulla with salazinic acid; cortex with usnic acid.
The species occurs in Lensk Region according to herbarium and own materials and has also been reported from Olekminsk Region (Vershinina et al. 2015) (Fig. 1C).

Specimens examined: LENSK REGION, $17 \mathrm{~km} \mathrm{E}$ from village Vitim $\left(59^{\circ} 27^{\prime} 12^{\prime \prime} \mathrm{N}, 112^{\circ} 55^{\prime} 58^{\prime \prime} \mathrm{E}\right)$, wood sorrel spruce forest, branches of Picea sp., 05.07.1989, leg. Zaharova V.I. (SASY, Us 7); right bank of the river Lena, near village Krestovaya (5946'5"N, $113^{\circ} 18^{\prime} 1$ "E), Pinus pumila-larch forest with cowberry, branches of Picea sp., 30.06.1989, leg. Isaev A.P. (SASY, Us 5).

\section{Usnea glabrescens (Nyl. ex Vain.) Vain.}

Thallus shrubby or subpendent, base blackened, fibrils present, soralia distinctly rounded, isidia absent. The main diagnostic features are its isotomic-dichotomous branches 
and distinctly rounded punctiform soralia.

Four chemotypes have been recorded: (1) medulla with salazinic and diffractaic acids, cortex with usnic acid; (2) medulla with psoromic acid, cortex with usnic acid; (3) medulla with thamnolic acid, cortex with usnic acid; (4) medulla without lichen substances, cortex with usnic acid.

The species occurs in Aldan, Kobyaisk, Lensk regions according to herbarium collections and own materials and also in Olekminsk Region (Vershinina et al. 2015) (Fig. 1D).

Specimens examined: ALDAN REGION, left bank of the river Aldan, orifice of the river Unil'ya, $78 \mathrm{~km}$ upper village Ugino $\left(58^{\circ} 45^{\prime} 36^{\prime \prime} \mathrm{N}, 128^{\circ} 2^{\prime} 24^{\prime \prime} \mathrm{E}\right)$, spruce-pine forest, 24.06.1980, leg. Zaharova V.I. (SASY, Us 74); stream Bezymyannyi $\left(58^{\circ} 44^{\prime} 40^{\prime \prime} \mathrm{N}, 126^{\circ} 21^{\prime} 48^{\prime \prime E}\right)$, alt. $491 \mathrm{~m}$, forest with spruce, birch, larch, deadwood, 11.07.2015, leg. Konoreva L.A. (LE); near town Aldan, bank of the river Bol'shoi Kuranah (58³8'33.6"N, 125²8'05.9"E), dark-coniferous forest and forest of small-leaved deciduous species, on the bark of Picea sp., 04.07.2015, leg. Chesnokov S.V. (LE); near town Aldan, "Radiogora" (58³6'34.9"N, $\left.125^{\circ} 22^{\prime} 025^{\prime \prime E}\right)$, on the bark of Salix sp., 04.07.2015, leg. Chesnokov S.V. (LE); $1 \mathrm{~km}$ to $\mathrm{E}$ from the river Delinda $\left(58^{\circ} 46^{\prime} 20.4^{\prime \prime} \mathrm{N}, 126^{\circ} 25^{\prime} 27.2^{\prime \prime E}\right)$, alt. $500 \mathrm{~m}\left(58^{\circ} 46^{\prime} 21^{\prime \prime} \mathrm{N}\right.$, $\left.126^{\circ} 25^{\prime} 27^{\prime \prime} \mathrm{E}\right)$, alt. $536 \mathrm{~m}$, fir forest near road, 12.07.2015, leg. Chesnokov S.V., Konoreva L.A. (LE); stream Lenskii, fir forest with larch (58 34'28"N, 12532'7"E), 06.07.2015, leg. Konoreva L.A. (LE). KOBYAISK REGION, near rivers Sagandzhi and Dyanyshki $\left(65^{\circ} 27^{\prime} 15^{\prime \prime} \mathrm{N}, 127^{\circ} 0^{\prime} 38^{\prime \prime E}\right)$, fir forest, on the branches of Picea sp., 04.07.1985, leg. Volotovskii K.A. (SASY, Us 9). LENSK REGION, near river Pilka (59 $\left.47^{\prime} 38^{\prime \prime} \mathrm{N}, 113^{\circ} 48^{\prime} 14^{\prime \prime} \mathrm{E}\right)$, larch forest with fir, on the branches of Picea sp. and Larix sp., 23.06.2002, leg. Egorova A.A. (SASY, Us 80); left bank of the river Lena,

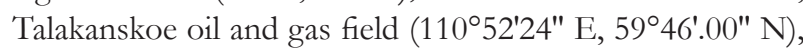
larch forest with pine and birch, on the bark of Betula sp., deadwood (110 $\left.42^{\prime} 49^{\prime \prime} \mathrm{E}, 59^{\circ} 55^{\prime} 5^{\prime \prime} \mathrm{N}\right)$, pine forest with fox berry and soil lichens, 11.09.2014, 08.09.2014, leg. Chikidov I.I. (SASY, Us 42, Us 45, Us 46); border with Irkutsk Region, right bank of the river Vitim, $4 \mathrm{~km}$ downstream from the river Talaya $\left(59^{\circ} 08^{\prime} 18^{\prime \prime} \mathrm{N}, 112^{\circ} 40^{\prime} 52^{\prime \prime} \mathrm{E}\right)$, mixed forest, on the bark of Betula sp., on the branches of Picea sp., $\left(59^{\circ} 08^{\prime} 22^{\prime \prime} \mathrm{N}, 112^{\circ} 41^{\prime} 21^{\prime \prime} \mathrm{E}\right)$, fir forest, on the branch of Picea sp., 12.06.2004, leg. Poryadina L.N. (SASY, Us 23, Us 28, Us 29, Us 25). MIRNYI REGION, left bank of the river Ulahan-Botuobuya, $700 \mathrm{~m}$ below river Arbangda-Siene $\left(61^{\circ} 22^{\prime} 9^{\prime \prime} \mathrm{N}, 112^{\circ} 24^{\prime} 41^{\prime \prime} \mathrm{E}\right)$, fir forest, trunk of the Betula sp., 15.08.2006, leg. Poryadina L.N. (SASY, Us 64, Us 65); reserve "Dzhunkun", fir forest, on the branches of Picea sp., 17.08.2006, leg. Poryadina L.N. (SASY, Us 21).

\section{Usnea hirta (L.) W.H. Wigg.}

Thallus shrubby, branched, base pale greenish or brownish, fibrils abundant, isidia numerous, papillae absent, soralia punctiform.

The main diagnostic features are its shrubby thallus, with numerous isidia and the absence of papillae.

Two chemotypes have been recorded: (1) medulla with squamatic and salazinic acids, cortex with usnic acid; (2) medulla without lichen substances, cortex with usnic acid. 1E).

The species was found in Aldan and Lensk regions (Fig.

Specimens examined: ALDAN REGION, stream Bezymyannyi (58 $\left.44^{\prime} 39.5^{\prime \prime} \mathrm{N}, 126^{\circ} 21^{\prime} 47.3^{\prime \prime} \mathrm{E}\right)$, forest with spruce, birch, larch, on the branch of Alnus sp., 11.07.2015, leg. Chesnokov S.V. (LE). LENSK REGION, right bank of the river Vitim $\left(59^{\circ} 08^{\prime} 22^{\prime \prime} \mathrm{N}, 112^{\circ} 41^{\prime} 21^{\prime \prime} \mathrm{E}\right)$, fir forest, on the branch of Picea sp., 13.06.2004, leg. Poryadina L.N. (SASY, Us 75).

\section{Usnea lapponica Vain.}

Thallus shrubby, branched, mainly anisotomic-dichotomous, base pale to blackened, fibrils abundant, isidia absent, papillae numerous, soralia large, becoming expanded and bracelet-like. The main diagnostic features are its shrubby, anisotomic-dichotomous branched thallus, with numerouspapillae and the absence of isidia.

Three chemotypes have been recorded: (1) medulla with salazinic acids, cortex with usnic acid; (2) medulla with thamnolic acid, cortex with usnic acid; (3) medulla without lichen substances, cortex with usnic acid.

The lichenicolous fungus, Lichenostigma maureri Hafellner, was found on U. lapponica.

This species occurs in Aldan, Kobyaisk, Lensk, Mirnyi, Neryungri, Olenek, Olekminsk, Tomponsk regions (Fig. 1F).

Specimens examined: ALDAN REGION, right bank of the river Aldan $\left(58^{\circ} 48^{\prime} 18^{\prime \prime} \mathrm{N}, 128^{\circ} 09^{\prime} 18.5^{\prime \prime} \mathrm{E}\right)$, larch forest with fir, Picea sp., 16.07.2015, leg. Poryadina L.N. (SASY, Us $86)$; right bank of the river Bol'shoi Nimnyr $\left(58^{\circ} 02^{\prime} 26.0^{\prime \prime} \mathrm{N}\right.$, $\left.125^{\circ} 29^{\prime} 53.7^{\prime \prime E}\right)$, alt. $861 \mathrm{~m}$, fir-pine-larch forest, 10.07.2015, leg. Chesnokov S.V. (LE); $1 \mathrm{~km}$ E from the river Delinda $\left(58^{\circ} 46^{\prime} 21^{\prime \prime N}, 126^{\circ} 25^{\prime} 27^{\prime \prime E}\right)$, alt. $536 \mathrm{~m}$, fir forest with birch and larch, 12.07.2015, leg. Konoreva L.A. (LE); stream Lenskii $\left(58^{\circ} 34^{\prime} 27^{\prime \prime} \mathrm{N}, 125^{\circ} 32^{\prime} 07.9^{\prime \prime} \mathrm{E}\right)$, alt. $775 \mathrm{~m}$, fir forest, on the bark of Picea sp. (58 $\left.34^{\prime} 28^{\prime \prime} \mathrm{N}, 125^{\circ} 32^{\prime} 07.9^{\prime \prime} \mathrm{E}\right)$, alt. $763 \mathrm{~m}$, fir forest with larch and Pinus pumila, 06.07.2015, leg. Chesnokov S.V., Konoreva L.A. (LE). KOBYAISK REGION, river Dyanyshka, $30 \mathrm{~km}$ upper river Sagandzhi (65 $19^{\prime} 20^{\prime \prime} \mathrm{N}$, $\left.126^{\circ} 29^{\prime} 40^{\prime \prime} \mathrm{E}\right)$, fir-larch-Pinus pumila-Duschekia sp. forest, fir forest, on the branches of Picea sp., 20.06.1985, 31.05.1985, leg. Volotovskii K.A. (SASY, Us 1, Us 11); near rivers Sagandzhi and Dyanyshki $\left(65^{\circ} 27^{\prime} 15^{\prime \prime} \mathrm{N}, 127^{\circ} 0\right.$ '38"E), fir forest, on the branches of Picea sp., 04.07.1985, leg. Volotovskii K.A. (SASY, Us 10). LENSK REGION, left bank of the river Lena, Talakanskoe oil and gas field $\left(110^{\circ} 25^{\prime} 35^{\prime \prime} \mathrm{N}\right.$, $\left.59^{\circ} 24^{\prime} 42^{\prime \prime} \mathrm{E}\right)$, fir-larch forest, on the branches of Picea sp., 08.09.2014, leg. Chikidov I.I., (SASY, Us 43, Us 44); near river Pilka $\left(59^{\circ} 47^{\prime} 38^{\prime \prime} \mathrm{N}, 113^{\circ} 48^{\prime} 14^{\prime \prime} \mathrm{E}\right)$, larch forest with fir, on the branches of Larix sp. and Picea sp., 23.06.2002, leg. Egorova A.A. (SASY, Us 79); stream Lenskii (58³4'27.5"N, $\left.125^{\circ} 32^{\prime} 07.9^{\prime \prime} \mathrm{E}\right)$, alt. $775 \mathrm{~m}$, fir forest, on the bark of fir, 06.07.2015, leg. Chesnokov S.V. (LE). MIRNYI REGION, left bank of the river Ulahan-Botuobuya, $700 \mathrm{~m}$ below river Arbangda-Siene $\left(61^{\circ} 22^{\prime} 9^{\prime \prime} \mathrm{N}, 112^{\circ} 24^{\prime} 41^{\prime \prime} \mathrm{E}\right)$, fir forest, on the bark and branch Picea sp., 15.08.2006, leg. Poryadina L.N. (SASY, Us 66, Us 67). NERYUNRGI REGION, near lake

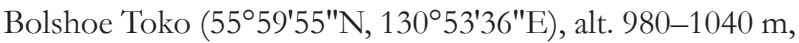
fir forest with alder, on the trunk and branches of fir, on the trunk of Alnus sp., 29.08.1987, leg. Fes'ko N.N. (SASY, 
Us 73). OLENEK REGION, left bank of the river Tyunga, below creek Sr. Salakuta $\left(66^{\circ} 35^{\prime} 3^{\prime \prime} \mathrm{N}, 115^{\circ} 50^{\prime} 28^{\prime \prime} \mathrm{E}\right)$, larchfir forest, 17.07.1957, leg. Dobretsova L.A. (SASY, Us 63). OLEKMINSK REGION, left bank of the river Biryuk $\left(60^{\circ} 22^{\prime} 12^{\prime \prime} \mathrm{N}, 119^{\circ} 29^{\prime} 25^{\prime \prime} \mathrm{E}\right)$, fir forest, mixed forest, on the branches of Picea sp., Larix sp. and Pinus sp., 15.07.2008, 16.07.2008, 21.07.2008, leg. Poryadina L.N. (SASY, Us 14, Us 15, Us 17, Us 19, Us 20); right bank of the river Biryuk $\left(60^{\circ} 22^{\prime} 12^{\prime \prime} \mathrm{N}, 119^{\circ} 29^{\prime} 25^{\prime \prime} \mathrm{E}\right)$, mixed forest, deadwood (Picea sp.), 16.07.2008, leg. Poryadina L.N. (SASY, Us 18); pipeline VSTO 1820-1833 km, stream Ozernyi $\left(60^{\circ} 15^{\prime} 39^{\prime \prime} \mathrm{N}\right.$, $121^{\circ} 42^{\prime} 31^{\prime \prime E)}$, alt. $449 \mathrm{~m}$, pine forest with birch, Pinus pumila, on the bark of Pinus sp., 18.07.2006, leg. Isaev A.P. (SASY, Us 83). TOMPONSK REGION, river Tukulan, $20 \mathrm{~km}$ from orifice river Temirdeeh $\left(63^{\circ} 57^{\prime} 41^{\prime \prime} \mathrm{N}, 132^{\circ} 38^{\prime} 57^{\prime \prime} \mathrm{E}\right)$, fir-larch forest, on the branches of Picea sp., 17.09.1990, leg. Akimova E.V. (SASY, Us 2,); basin of the river Aldan, right bank of the river Tompo, near village Krest-Hal'dzhai $\left(62^{\circ} 47^{\prime} 7^{\prime \prime} \mathrm{N}, 134^{\circ} 37^{\prime} 30^{\prime \prime} \mathrm{E}\right)$, fir forest, on the branches of Picea sp., 20.07.2010, leg. Zaharova V.I. (SASY, Us 22).

\section{Usnea longissima Ach.}

Thallus pendulous, long, base pale to blackened, the main stem covered with a persistent cortex. Primary branches with numerous fibrils, papillae absent or few, soralia punctiform, papillae absent or few. The main diagnostic features are its pendulous thallus, draping horizontal branches, and the main stem with a persistent cortex.

Three chemotypes have been recorded: (1) medulla with salazinic acids, cortex with usnic acid; (2) medulla with salazinic, barbatic acids, fatty acids, cortex with usnic acid; (3) medulla with salazinic, evernic, diffractaic acids, cortex with usnic acid.

The species occurs in Aldan and Neryungri regions (Fig. 1G).

Specimens examined: ALDAN REGION, Tokinskii Stanovik, basin of the river Algama, river Tarynnah $\left(56^{\circ} 0^{\prime} 32^{\prime \prime} \mathrm{N}, 129^{\circ} 39^{\prime} 52^{\prime \prime} \mathrm{E}\right)$, mixed forest, on the branches of Picea sp., 19.07.2000, leg. Sofronova E.V. (SASY, Us 49). NERYUNGRI REGION, near lake Bol'shoe Toko (5559'55"N, 13053'37"E), alt. 980-1040 m, fir forest with Duschekia sp., on the trunk and branches of Picea sp., 29.08.1987, leg. Fes'ko N.N. (SASY, Us 71, Us 72); range Tokinskii Stanovik, northern macroslope, reserve "Bol'shoe

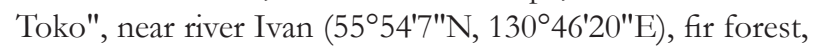
Picea sp., 07.07.1986, leg. Volotovskii K.A. (SASY, Us 50).

\section{Usnea subfloridana Stirt.}

Thallus shrubby to subpendent, branched, base blackened, fibrils present, isidia and papillae numerous, soralia typically punctiform, and bearing short numerous isidia. The main diagnostic features are its shrubby to subpendent thallus, punctiform soralia and the numerous isidia.

Three chemotypes have been recorded: (1) medulla with squamatic acid, cortex with usnic acid; (2) medulla with thamnolic acid, cortex with usnic acid; (3) medulla without lichen substances, cortex with usnic acid.

The lichenicolous fungus, Lichenostigma maureri Hafellner, was found on U. subfloridana.
The species is widespread in Sakha Republic and occurs in Aldan, Kobyask, Lensk, Neryungri, Olekminsk Regions (Fig. 1H).

Specimens examined: ALDAN REGION, right bank of the river Aldan $\left(58^{\circ} 49^{\prime} 52.1^{\prime \prime} \mathrm{N}, 127^{\circ} 42^{\prime} 45.6^{\prime \prime} \mathrm{E}\right)$, fir-larch forest, on the branches of Picea sp., 21.07.2015, leg. Poryadina L.N. (SASY, Us 82); near town Aldan, bank of the river Bol'shoi Kuranah (58³8'33.6"N, 125²8'05.9"E), dark-coniferous forest and forest of small-leaved deciduous species, on the bark of Picea sp., 04.07.2015, leg. Chesnokov S.V. (LE); $1 \mathrm{~km}$ E from river Delinda (58 $46^{\prime} 21^{\prime \prime N}$, $\left.126^{\circ} 25^{\prime} 27^{\prime \prime} \mathrm{E}\right)$, fir forest with birch and larch, 12.07.2015, leg. Konoreva L.A. (LE); left bank of the river Chul'man $\left(56^{\circ} 51^{\prime} 49^{\prime \prime} \mathrm{N}, 124^{\circ} 54^{\prime} 14^{\prime \prime E}\right)$, alt. $636 \mathrm{~m}$, poplar-willow forest with larch, 06.07.2015, leg. Konoreva L.A. (LE); stream

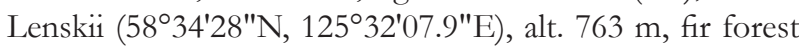
with larch and Pinus pumila, 06.07.2015, leg. Konoreva L.A. (LE). KOBYAISK REGION, orifice of the river Byrand'ya $\left(66^{\circ} 13^{\prime} 49^{\prime \prime} \mathrm{N}, 126^{\circ} 58^{\prime} 36^{\prime \prime E}\right)$, larch forest with poplar and chosenia, 06.08.1961, leg. Gruzdev P.V. (SASY, Us 81). LENSK REGION, right bank of the river Lena, near village Krestovaya $\left(59^{\circ} 46^{\prime} 5^{\prime \prime} \mathrm{N}, 113^{\circ} 18^{\prime} 1 " \mathrm{E}\right)$, fir-Pinus pumila-larch forest, on the branches of Picea sp., 30.06.1989, leg. Isaev A.P. (SASY, Us 3, Us 4, Us 6); orifice of the river Pilka (right bank of the river Lena) $\left(60^{\circ} 7^{\prime} 21^{\prime \prime} \mathrm{N}, 113^{\circ} 55^{\prime} 57^{\prime \prime} \mathrm{E}\right)$, fir forest, on the branches of Picea sp. and Larix sp., leg. Egorova A.A. (SASY, Us 76, Us 77); left bank of the river Lena, Talakanskoe oil and gas field $\left(59^{\circ} 55^{\prime} 5^{\prime \prime} \mathrm{N}, 110^{\circ} 42^{\prime} 49^{\prime \prime} \mathrm{E}\right)$, fir-larch forest, on the bark of Pinus sp., deadwood, 08.09.2014, leg. Chikidov I.I. (SASY, Us 45, Us 47); border with Irkutsk Region, right bank of the river Vitim, $4 \mathrm{~km}$ downstream from the river Talaya $\left(59^{\circ} 08^{\prime} 18^{\prime \prime} \mathrm{N}, 112^{\circ} 40^{\prime} 52^{\prime \prime} \mathrm{E}\right)$, mixed forest, deadwood, on the branches of Picea sp., 12.06.2004, leg. Poryadina L.N. (SASY, Us 26, Us 53, Us 62). NERYUNGRI REGION, near town Neryungri, near river Malyi Berkakit, larch forest, on the branches of Larix sp., 29.06.1976, leg. Perfil'eva V.I. (SASY, Us 59); near lake Bol'shoe Toko (555' $55^{\prime \prime} \mathrm{N}, 130^{\circ} 53^{\prime} 37^{\prime \prime E}$ ), alt. 980-1040 m, fir forest with Duschekia sp., on the trunk and branches of Picea sp., on the trunk of Duschekia sp., 29.08.1987, leg. Fes'ko N.N. (SASY, Us 68, Us 69, Us 70). OLEKMINSK REGION, right bank of the river Biryuk (60²2'12"N, 119 $\left.29^{\circ} 25^{\prime \prime} \mathrm{E}\right)$, mixed forest, deadwood of Picea sp., 16.07.2008, leg. Poryadina L.N. (SASY, Us 18); left bank of the river Biryuk $\left(60^{\circ} 22^{\prime} 12^{\prime \prime} \mathrm{N}, 119^{\circ} 29^{\prime} 25^{\prime \prime} \mathrm{E}\right)$, fir forest, on the branches of Picea sp., 15.07.2008, leg. Poryadina L.N. (SASY, Us 16). TOMPONSK REGION, right bank of the river Vostochnaya Handyga, near village Teplyi Klyuch (62 $46^{\prime} 384^{\prime \prime N}$, $\left.136^{\circ} 47^{\prime} 280^{\prime \prime} \mathrm{E}\right)$, alt. $290 \mathrm{~m}$, pine-fir forest, on the branches of Picea sp., 07.07.2011, leg. Poryadina L.N. (SASY, Us 48); river Tukulan, stream Tuora-Tukulan (635 $57^{\prime} 41^{\prime \prime N}$, 132³8'57"E), 06.09.1990, leg. Kirillina S.N. (SASY, Us 30); river Tukulan $\left(63^{\circ} 57^{\prime} 41^{\prime \prime} \mathrm{N}, 132^{\circ} 38^{\prime} 57^{\prime \prime} \mathrm{E}\right)$, on the branches of Larix sp., 05.09.1990, leg. Kirillina S.N. (SASY, Us 40). HANGALASSK REGION, right bank of the river Lena, nature park "Lenskie stolby", on the branches of Larix sp., 18.06.1972, leg. Perfil'eva V.I. (SASY, Us 56).

\section{ACKNOWLEDGEMENTS}


We would like to thank the head of the herbarium of the Institute for Biological Problems of Cryolithozone of Siberian Branch of RAS (SASY) Zaharova V.I. for allowing us to study material. We are grateful to Sophronova E.V. for providing a blank map and Zhurbenko M.P. for identifying lichenicolous fungi. Ivanova E.I. is gratefully acknowledged for help in organizing field work. The authors would like to thank William Purvis for correcting English. The study was financially supported by Russian Foundation for Basic Research (grant 15-44-05105).

\section{LITERAT URE CITED}

Ahti, T., S.Y. Kondratyuk, I. Kärnefelt \& A. Thell 2015. Nomenclatural corrections and notes on some taxa in the Teloschistaceae (lichenized ascomycetes). Graphis Scripta 27(1-2):37-41.

Andreev, M.P. 2004. New taxonomic combinations for lecidioid lichens. Novosti sistematiki nizshikh rastenii 37: 188-191 (in Russian). [Анареев М.П. 2004. Новые таксономические комбинации Аля мецидеоидных шайников // Новости систематики низших растений. Вып. 37. С. 188-191].

Articus, K. 2004. Neuropogon and the phylogeny of Usnea s.l. (Parmeliaceae, Lichenized Ascomycetes). Taxon 53(4): 925-934.

Chesnokov, S.V., L.A. Konoreva, L.N. Poryadina, E.S. Kuznetsova, D.E. Himelbrant, O.A. Kataeva \& M.P. Andreev 2015. New and rare lichens from Sakha Republic (Yakutia). Vestnik Tverskogo Universiteta 4:174-185 (in Russian with English summary). [Чесноков C.B.,

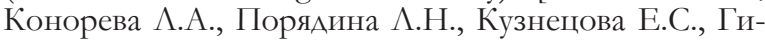
мельбрант А.Е., Катаева О.А., Андреев М.П. 2015. Новые и интересные находки мишайников Аля Республики Саха (Якутия) // Вестник Тверского государственного университета. Вып. 4. С. 174-185].

Chesnokov, S.V., L.A. Konoreva, A.P. Yatsyna, M.P. Andreev, L.N. Poryadina, J. Vondrak \& D.E. Himelbrant 2016. New and rare lichens from Sakha Republic (Yakutia). II. Vestnik Tverskogo Universiteta 4:210-240 (in Russian with English summary). [Чесноков С.В., Конорева А.А., Яцына А.П., Анареев М.П., Порядина М.Н., ВонАрак Я., Гимельбрант А.Е. Новые и интересные нахоАки Аишайников Аля Республики Саха (Якутия). II // Вестник Тверского государственного университета. Вып. 4. С. 210-240].

Clerc, P. 2011. Usnea. In: Nordic lichen flora 4: 107-127.

Culberson, C.F. \& K. Ammann 1979. Standardmethode zur Dünnschichtchromatographie von Flechtensubstanzen.
Herzogia 5:1-24.

Halonen, P., P. Clerc, T. Gowardb, I. Brodo \& K. Wulff 1998. Synopsis of the Genus Usnea (Lichenized Ascomycetes) in British Columbia, Canada). The Bryologist 101(1): 36-60.

Konoreva, L.A., S.V. Chesnokov \& E.A. Davydov 2016. Stictis and Schizoxylon (Stictidaceae, Ostropales) in Russia. Herzogia 29(2): 06-711.

Kranner, I., R.P. Beckett \& A.K. Varma 2002. Protocols in lichenology. Springer-Verlag, Berlin \& Heidelberg, 580 pp.

Poryadina, L.N. 2005. Lichens. In: Plant diversity of Yakutia, (N.S. Danilova, ed), pp. 126-149 (in Russian). [Порядина А.Н. 2005. Аишайники // Разнообразие растительного мира Якутии / под ред. Н.С. Аанилова. Новосибирск: СО РАН. С. 126-149].

Randlane, T., T. Tõrra, A. Saag \& L. Saag. 2009. Key to European Usnea species. Bibliotheca Lichenologica 100: 419-462.

Søchting, U. \& G. Figueras. 2007. Caloplaca lenae sp. nov., and other Caloplaca species with caloploicin and vicanicin. The Lichenologist 39(1):7-14.

Vershinina, S.E., D.E. Himelbrant, E.S. Kuznetsova, L.M. Gabysheva \& E.M. Gabyshev 2012. The first data on lichen flora of state nature reserve Olyokminsky (Sakha-Yakutia Republic). Vestnik Tverskogo Universiteta 25(3):138-149 (in Russian with English summary). Вершинина С.Э., Гимельбрант А.Е., Кузнецова Е.С., Габышева А.М., Габышев Э.М. 2012. Первые сведения о михенофлоре государственного заповедника Олекминский (Республика Саха-Якутия) // Вестник Тверского государственного университета. Вып. 25, № 3. C. 138-149].

Vershinina, S.E., D. E. Himelbrant, E. S. Kuznetsova, L. M. Gabysheva \& Ed. M. Gabyshev. 2015. Addition to the lichen flora of state nature reserve Olyokminsky (SakhaYakutia Republic). Proceedings of state nature reserve Olyokminsky 1:90-107. [Вершинина С.Э., Гимельбрант А.Е., Кузнецова Е.С., Габышев Э.М., Габышева А.М. Аопол-

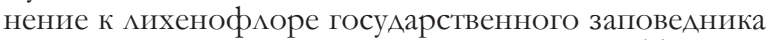
«Олёкминский» (Республиика Саха (Якутия)) // Труды Государственного природного заповедника «О Аёкминский». Вып. 1. Якутск: Издательский дом СВФУ, 2015. C. 90-107].

Zhurbenko, M.P., M.K. Raynolds, D.A. Walker \& N.V. Matveeva 2005. Lichens and lichenicolous fungi from the Kolyma delta region, Russian Arctic. Graphis scripta 17: 27-31.

Zhurbenko, M.P. \& S.E. Vershinina. 2014. Opegrapha bryoriae sp. nov. and other lichenicolous fungi from Asian Russia. Herzogia 27(1):93-109. 